\title{
Effect of nutrient management on growth parameters in knolkhol (Brassica oleracea var. gongylodes)
}

\author{
MUTUM BABYCHAND*, K. HARIPRIYA AND S. ANUJA \\ Department of Horticulture, Faculty of Agriculture, Annamalai University, ANNAMALAINAGAR (T.N.) INDIA
}

\begin{abstract}
The present field experiment was carried out with Knolkhol cv. EARLY WHITE VIENNA in a Randomized Block Design with three replications at Department of Horticulture Faculty of Agriculture, Annamalai University during 2015. The experiment comprised of 10 different combinations of five different sources of nutrients including organic, inorganic and biofertilizers. The effect of different treatments were observed and noted that plants treated with 50\% RDF+VC @ $5 \mathrm{t} \mathrm{ha}^{-1}+$ biofertilizers @ $2 \mathrm{~kg}$ ha $^{-1}\left(\mathrm{~T}_{3}\right)$ registered maximum growth parameters viz., plant height, number of leaves per plant, leaf length, leaf width, root length and number of secondary roots in knolkhol cv. EARLY WHITE VIENNA.
\end{abstract}

Key Words : Knol khol, Vermicompost, FYM, Biofertilizers

View Point Article : Babychand, Mutum, Haripriya, K. and Anuja, S. (2017). Effect of nutrient management on growth parameters in knolkhol (Brassica oleracea var. gongylodes). Internat. J. agric. Sci., 13 (1) : 46-48, DOI:10.15740/HAS/IJAS/13.1/46-48.

Article History : Received : 02.08.2016; Revised : 05.11.2016; Accepted : 09.12.2016

\footnotetext{
* Author for correspondence:
} 